\title{
ALTERNATIF BANGUNAN AIR UNTUK PENYEDIAAN AIR BAKU DI PULAU GILI-GILI, NUSA TENGGARA BARAT
}

\author{
Diah Affandi \\ Puslitbang Sumberdaya Air, Kementerian Pekerjaan Umum \\ Jl.Ir. H.Juanda No. 193 Bandung
}

\begin{abstract}
In order to meet water needs during the dry season in West Nusa Tenggara (NTB), particularly on small islands in the NTB area needed a facility that can accommodate the rain water in the rainy season, so water supply can be used during the dry season. Characteristics of land in coastal areas in particular, other than flat land also contains sand, so the soil tends to have relatively high permeabilities. To build waterworks facilities suitable to local conditions then, required an assessment of alternative types of water structure adapted to the geological conditions and availability of building materials to be used.
\end{abstract}

Keywords : Karakteristik Tanah, Alternative Bangunan Air

\section{PENDAHULUAN}

\subsection{Latar Belakang}

Dalam rangka meningkatkan sumber daya air di Nusa Tenggara Barat, maka direncanakan pembuatan beberapa alternative model penampung air untuk mengantisipasi keperluan air baku bagi penduduk setempat. Di samping untuk memberi masukan bagi Pemerintah Daerah Tingkat I Nusa Tenggara Barat, Kabupaten Lombok Barat, yang telah menetapkan bahwa kawasan mulai dari Senggipamenang dan Gili-Gili termasuk kawasan wisata, maka untuk meningkatkan dan mengembangkan potensi di daerah wisata tersebut dibutuhkan sarana dan prasarana penunjang, diantaranya adalah ketersediaan air tawar dalam jumlah dan kualitas yang cukup baik.

Tidak semua kawasan wisata itu mengalami kendala yang berkaitan yang berkaitan dengan penyediaan air bersih. Kawasan yang sangat membutuhkannya adalah di pulau-pulau kecil tepatnya di daerah Gili-Gili diantaranya Gili Terawangan, Gili Meno dan Gili Air. Untuk mengatasi masalah tersebut, diperlukan suatu pengkajian mengenai bangunan air yang tepat untuk digunakan sebagai bangunan yang dapat menampung air pada musim hujan, sehingga pada musim kemarau air tesebut dapat dipergunakan (3).

Salah satu upaya untuk meningkatkan pelayanan umum dalam rangka membantu meningkatkan taraf hidup penduduk di pulaupulau kecil yang sulit air, adalah dengan mengadakan penyediaan air baku untuk keperluan penduduk sehari-hari. Pengkajian sumber air misalnya air hujan, air permukaan serta air tanah yang mempunyai potensi untuk ditampung perlu dilakukan untuk mencari alternative pemanfaatan sumber air baku yang optimum.

\subsection{Maksud dan Tujuan}

Pengkajian ini dimaksudkan untuk menentukan jenis bangunan air yang sesuai untuk penyediaan air baku di pulau Gili-Gili, NTB. Tujuannya guna memenuhi kebutuhan air baku penduduk untuk berbagai keperluan terutama pada musim kemarau.

\subsection{Ruang Lingkup}

Lingkup kegiatan meliputi :

a. Pengumpulan data dan informasi dari referensi.

b. Pengujian permeabilitas di lapangan.

c. Pengujian contoh tanah di laboratorium.

d. Pemetaan Geoteknik.

e. Analisa jenis bangunan air yang tepat di daerah penelitian.

\subsection{Metode penelitian}

Metodologi yang dipergunakan dalam penelitian ini berupa :

a. Pemetaan, pengukuran langsung di lapangan, perhitungan dan analisis data di lapangan maupun hasil uji laboratorium.

b. Pengumpulan data primer di lapangan dan data sekunder dari hasil penelitian terdahulu.

c. Studi geologi regional berupa studi peta geologi regional untuk mengetahui gambaran penyebaran lapisan batuan di permukaan bumi, berdasarkan peta geologi skala 1 : 250.000 .

d. Pengambilan contoh tanah dilakukan di lokasi penelitian yang cukup mewakili dan di 
daerah lainnya di sekitar Lombok Barat, yang diperkirakan dapat digunakan untuk bahan bangunan air.

e. Pengujian di laboratorium : contoh tanah yang diambil diuji untuk mengetahui parameter tanah, antara lain uji indeks properties, triaksial, pemadatan dan konsolidasi tanah.

f. Analisa dan evaluasi data: melakukan analisis dan perhitungan untuk menentukan alternatif jenis bangunan air yang sesuai di daerah penelitian guna penyediaan air baku.

\subsection{Lokasi Kegiatan (Pengambilan Contoh Tanah)}

Daerah pengkajian terletak di desa Gili Indah yang terdiri dari Pulau Gili Terawangan Gili Meno, dan Gili Air. Daerah ini termasuk wilayah kecamatan Pamenang, Kabupaten Lombok Barat. Lokasi penelitian dapat dicapai melewati jalan darat dengan 2 alternatif. Alternatif pertama dari Mataram ke arah Desa Batulayar-SenggigiPamenang-Sire, dengan jarak tempuh sekitar 36 km. Untuk mencapai lokasi tiga Gili tersebut harus menggunkan transportasi laut (motor boat) lewat lokasi penyebrangan dari Bangsal. Alternatif kedua dari Mataram ke arah Gunungsari-Pusuk-Pamena-Sire dengan jarak tempuh sekitar $30 \mathrm{~km}$, pencapaian lokasi tiga Gili sama seperti pada alternatif pertama. Secara lengkap lokasi penelitian dapat diperiksa pada gambar $1{ }^{(3)}$

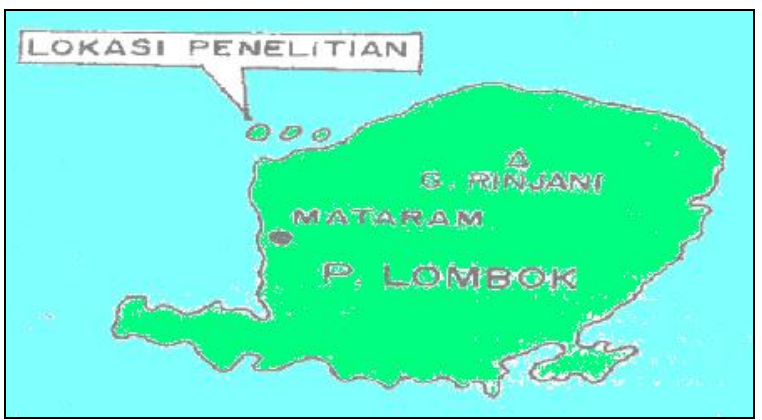

Gambar 1. Peta Lokasi Peneltian

\section{DESKRIPSI DAERAH PENELITIAN}

\subsection{Gambaran umum}

\subsubsection{Kependudukan}

Daerah penelitian termasuk wilayah Desa Pamenang Barat yang meliputi Dusun Klui, Pamenang, Gili Air, Gili Meno, Gili Terawangan, termasuk dalam Kecamatan Tanjung, dengan jumlah penduduk sekitar 60.404 orang. Salah satu desa pulau yang ada di Kecamatan Tanjung adalah Desa Gili Indah yang terdiri dari 3 pulau, yaitu Gili Air, Gili Meno dan Gili Terawangan dengan jumlah penduduk 2.905 jiwa dan luas wilayah keseluruhan $6,88 \mathrm{~km}^{2}$ (tabel 1). Daerah Desa Gili Indah adalah salah satu daerah wisata di Pulau Lombok, mata pencaharian penduduk umumnya adalah nelayan dan juga sebagai pemandu wisatawan yang datang ke Desa Gili Indah, serta pedagang. Selain penduduk asli Desa Gili Indah, juga ada pendatang yang berasal dari Pulau Lombok (2).

Tabel 1. Jumlah Penduduk di Pulau Gili-Gili Kecamatan Pamenang, NTB

\begin{tabular}{|l|l|l|l|}
\hline \multicolumn{1}{|c|}{ Desa } & \multicolumn{1}{|c|}{ Pulau } & $\begin{array}{c}\text { Luas } \\
\left(\mathbf{k m}^{2}\right)\end{array}$ & $\begin{array}{c}\text { Jml Penduduk } \\
\text { I Desa (jiwa) }\end{array}$ \\
\hline Gili Indah & Gili Air & 1,88 & 1.299 \\
\hline Gili Indah & Gili Meno & 1,50 & 500 \\
\hline Gili Indah & Gili Terawangan & 3,50 & 1.106 \\
\hline Jumlah & 3 pulau & 6,88 & 2.905 \\
\hline
\end{tabular}

\subsubsection{Iklim dan Curah Hujan}

Data mengenai iklim dan curah hujan untuk daerah penelitian diwakili oleh stasiun pengamat BPP Gunungsari, BP Tanjung dan stasiun Meteorologi Selaparang, Mataram. Data yang didapat sebagai berikut :

- $\quad$ Curah hujan rata-rata bulanan $=499,5-$ $1879,5 \mathrm{~mm}$

- Intensitas hujan = $18-25,8 \mathrm{~mm} / \mathrm{hh}$

- Suhu udara rata-rata bulanan $=20,1-32^{\circ} \mathrm{C}$

- Penyinaran matahari bulanan $=55,16 \%$

- Kelembaban udara bulanan = $50-97 \%$

- Kecepatan angina rata-rata $=8,75 \mathrm{knot} / \mathrm{jam}$ (arah relatif barat-timur)

\subsubsection{Tata Guna Lahan}

Morfologi lahan di daerah penelitian yang merupakan daerah kawasan wisata, umumnya berupa pedataran dan dataran antar bukit kecil. Sebagian dari derah ini digunakan untuk cottage, restoran, pertokoan dan permukiman.

\subsection{Geologi}

Data geologi untuk Pulau Lombok berdasarkan hasil pemetaan yang dilakukan oleh Syahrir dkk tahun 1989, menyatakan bahwa batuan yang tersingkap terdiri dari batuan gunung api, batuan sedimen dan batuan terobosan, yang umurnya berkisar dari Tersier sampai Kuarter. Satuan batuan tertua yang tersingkap adalah formasi yang terdiri dari breksi, lava dan tufa dengan lensa batugamping yang mengandung bijih sulfida dan urat kuarsa. 


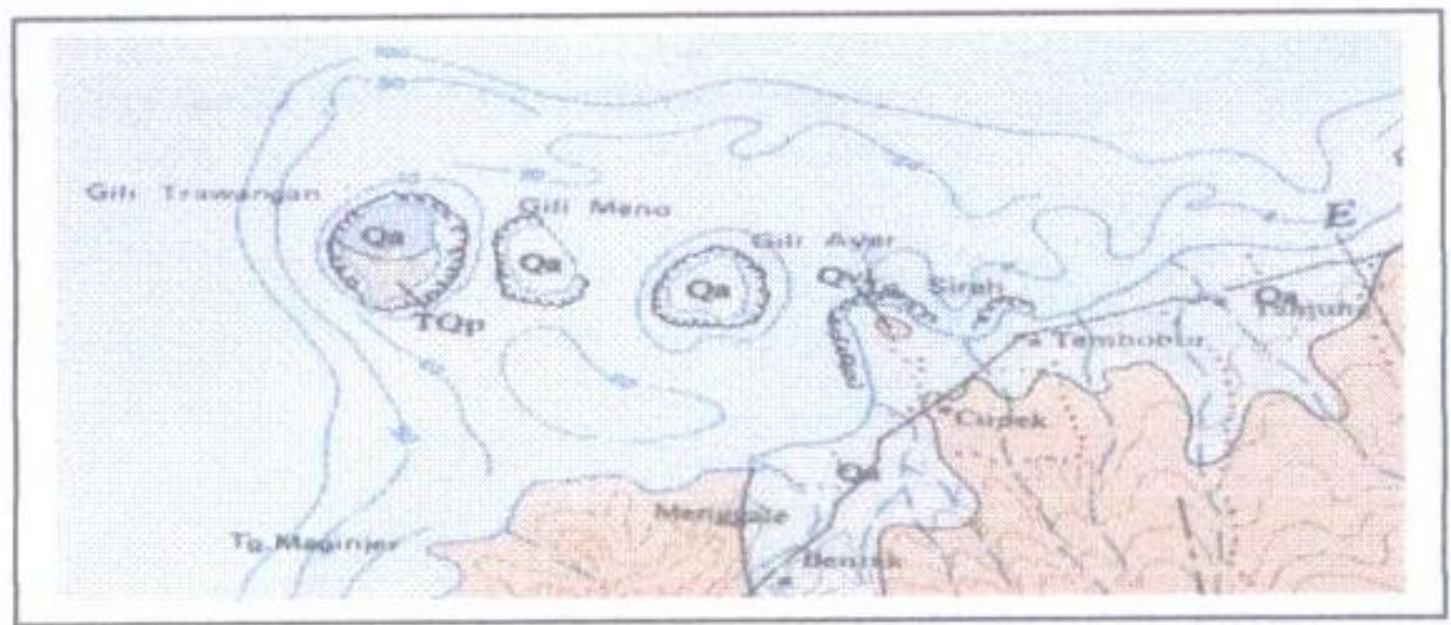

Gambar 2. Peta Geologi Daerah Peneltian

Berdasarkan Peta Geologi Lembar Lombok, skala $1: 250.000$ yang dibuat oleh Andi Mangga cs tahun 1995, daerah penelitian tersusun oleh formasi Kalipalung (TQp), batugamping, koral dan endapan aluvium dengan urutan dari yang tertua sampai termuda adalah sebagai berikut :

1) Formasi Kalipalung (TQp) merupakan batuan vulkanik tua yang berumur Plio-Plistosen, berupa selang-seling antara breksi gampingan dan lava. Breksi berwarna kelabu tua, kompak, bersusunan andesit sampai basalt dengan matriks batupasir tuf gampingan yang berbutir kasar. Lava berwarna kelabu, bersusunan andesit sampai basalt, menunjukan struktur aliran.

2) Batugamping koral berwarna putih kekuningan, tidak berlapis, dan singkapannya mengelilingi pulau Gili-Gili. Batugamping koral berada di atas batuan vulkanik secara tidak selaras, pertumbuhan koral masih berlangsung sampai saat ini.

Aluvium (Qa) ; merupakan hasil rombakan dari semua batuan yang telah ada yang berlangsung sampai saat ini. Litologinya terdiri dari lanau, pasir, kerikil dan pecahan koral ${ }^{(2)}$.

\section{HASIL PENGAMATAN}

\subsection{Data Lapangan}

Berdasarkan dari data hasil survei geologi yang telah dilaksanakan di daerah Gili Meno dan Gili Air, morfologi daerah ini merupakan daerah pedataran, kecuali di daerah Gili Terawangan yang terdapat tonjolan bukit dengna tinggi sekitar $30 \mathrm{~m}$, dimana terdapat $+/-5^{\circ}$ dengan ketinggian sekitar 1-13 m. Litologi penyusun geologi daerah ini secara umum adalah aluvium pantai berupa pasir, lanau, pecahan koral dan pasir batuapung.

\subsection{Permeabilitas Tanah}

Tujuan dari pengujian ini untuk mendapatkan nilai rembesan $(k)$, yaitu nilai yang menyatakan kemudahan aliran air melalui suatu contoh tanah. Uji percobaan permeabilitas dapat dilakukan di laboratorium maupun di lapangan, dari uji laboratorium dapat juga dibuat grafik hubungan antara koefisien permeabilitasnya dengan kadar air.

Uji permeabilitas di lapangan digunakan untuk mengukur rata-rata aliran air melalui suatu jenis tanah. Ada beberapa jenis percobaan yang dapat dilaksanakan antara lain :

a. Percobaan dengan menaikkan muka air

b. Percobaan dengan menurunkan muka air

c. Percobaan dengan muka air tetap

d. Percobaan Packer

e. Percobaan dengan pemompaan

Percobaan yang dilakukan pada penelitian ini adalah dengan cara Falling Head (menurunkan muka air) karena dengan cara menurunkan muka air termasuk percobaan yang paling sederhana dan cocok untuk tanah berbutir halus. Pada percobaan ini dipakai rumus (1):

\section{$\mathrm{K}=2,3 \times \mathrm{r} / 4 \mathrm{t} \times \log \mathrm{ho} / \mathrm{ht}$}

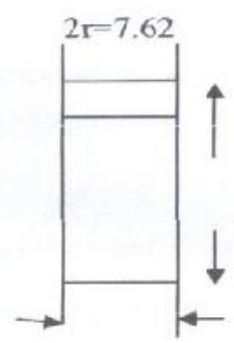


Dimana :

$$
\begin{aligned}
& \text { ho }=\text { tinggi tabung } \\
& \text { ht }=\text { tinggi muka air turun } \\
& r \quad=\text { jari-jari tabung } \\
& \text { t } \quad=\text { waktu yang diperlukan mencapai } \\
& \text { penurunan tertentu. }
\end{aligned}
$$

Tabel 2. Hasil Pengukuran Permeabilitas di Daerah Gili Air, NTB

\begin{tabular}{|c|c|c|c|c|c|}
\hline No. & $\mathbf{t}$ (menit) & ht (cm) & ho (cm) & Log ho/ht & k (cm/det) \\
\hline \hline 1 & 15 & 19,5 & 50 & 0,215 & $5,23 \times 10^{-4}$ \\
2 & 15 & 15,0 & 50 & 0,155 & $3,77 \times 10^{-4}$ \\
3 & 15 & 12,6 & 50 & 0,126 & $3,06 \times 10^{-4}$ \\
4 & 15 & 10,5 & 50 & 0,102 & $2,49 \times 10^{-4}$ \\
5 & 15 & 9,0 & 50 & 0,086 & $2,09 \times 10^{-4}$ \\
6 & 15 & 8,0 & 50 & 0,076 & $1,85 \times 10^{-4}$ \\
7 & 15 & 6,0 & 50 & 0,056 & $1,35 \times 10^{-4}$ \\
8 & 15 & 6,0 & 50 & 0,056 & $1,35 \times 10^{-4}$ \\
9 & 15 & 6,0 & 50 & 0,056 & $1,35 \times 10^{-4}$ \\
\hline
\end{tabular}

Tabel 3. Hasil pengukuran permeabilitas di Daerah Gili Air Terawangan, NTB

\begin{tabular}{|c|c|c|c|c|c|}
\hline No & $\mathbf{t}$ (menit) & ht (cm) & ho (cm) & Log ho/ht & k (cm/det) \\
\hline \hline 1 & 15 & 20,0 & 50 & 0,222 & $7,21 \times 10^{-4}$ \\
2 & 15 & 14,5 & 50 & 0,149 & $4,83 \times 10^{-4}$ \\
3 & 15 & 10,5 & 50 & 0,102 & $3,32 \times 10^{-4}$ \\
4 & 15 & 9,0 & 50 & 0,086 & $2,48 \times 10^{-4}$ \\
5 & 15 & 8,0 & 50 & 0,076 & $2,46 \times 10^{-4}$ \\
6 & 15 & 7,0 & 50 & 0,066 & $2,13 \times 10^{-4}$ \\
7 & 15 & 6,0 & 50 & 0,056 & $1,80 \times 10^{-4}$ \\
8 & 15 & 6,0 & 50 & 0,056 & $1,80 \times 10^{-4}$ \\
9 & 15 & 6,0 & 50 & 0,056 & $1,80 \times 10^{-4}$ \\
\hline
\end{tabular}

Hasil pengujian permeabilitas pada tanah ini menunjukkan angka koefisien permeabilitas yang berkisar antara $1,455 \times 10^{-4} \mathrm{~cm} / \mathrm{det}$, hal ini menunjukan banhwa tanah tersebut tidak begitu kedap air

\subsection{Data Laboratorium}

Bahan bangunan timbunan (lempung) yang didapat didaerah penelitian adalah sebagai

\begin{tabular}{|c|c|c|}
\hline Uraian & Simbol (satuan) & Nilai \\
\hline Kadar air & Wn (\%) & 29,42 \\
\hline Berat Jenis & Gs & 2,66 \\
\hline Angka pori & E & 0,894 \\
\hline Porositas & $n(\%)$ & 45,274 \\
\hline Berat isi kering & $\gamma d\left(\mathrm{~g} / \mathrm{cm}^{3}\right)$ & 47,20 \\
\hline Berat isi & $\gamma n\left(\mathrm{~g} / \mathrm{cm}^{3}\right)$ & 1,51 \\
\hline \multicolumn{3}{|l|}{ Batas Atterberg } \\
\hline Batas Cair & LL (\%) & 39,64 \\
\hline Batas Plastis & PL (\%) & 29,68 \\
\hline $\begin{array}{l}\text { Indeks Plastis } \\
\text { Batas Susut }\end{array}$ & $\begin{array}{l}\text { PI (\%) } \\
\text { SL (\%) }\end{array}$ & $\begin{array}{c}10,16 \\
25,8\end{array}$ \\
\hline \multicolumn{3}{|l|}{ Analisis ukuran butir } \\
\hline Kerikil & Gravel (\%) & - \\
\hline Pasir & Sand (\%) & 40,14 \\
\hline Lanau & Silt (\%) & 40,14 \\
\hline Lempung & Clay (\%) & 19,72 \\
\hline \multicolumn{3}{|l|}{ Pemadatan } \\
\hline Kadar air optimum & OMC (\%) & 22,60 \\
\hline Berat isi kering & $\gamma d\left(\mathrm{~g} / \mathrm{cm}^{3}\right)$ & 1,42 \\
\hline \multicolumn{3}{|l|}{ Kuat Geser } \\
\hline Kohesi & $\mathrm{C}\left(\mathrm{kg} / \mathrm{cm}^{2}\right)$ & 0,28 \\
\hline Sudut Geser & $f\left({ }^{\circ}\right)$ & 28,26 \\
\hline Permeabilitas & k (cm/det) & $1,44 \times 10^{-5}$ \\
\hline \multirow[t]{2}{*}{ Konsolidasi } & $\mathrm{Cv}$ & $3,46 \times 10^{-3}$ \\
\hline & $\mathrm{Cc}$ & 0,209 \\
\hline
\end{tabular}
berikut :
Tabel 4. Hasil Pengujian Laboratorium Terhadap Contoh Tanah Dari Daerah Tanjung, Mataram NTB

\subsection{Hasil Pemetaan Geoteknik}

Berdasarkan kesamaan litologinya, cara terjadinya dan sifat fisik tanah secara umum, tanah dan batuan di daerah penelitian dikelompokkan menjadi 3 satuan geologi. Uraian tentang satuan geologi teknik untuk tiap-tiap daerah adalah ditunjukkan pada tabel 5 .

\subsection{Bahan Bangunan}

Potensi bahan bangunan yang terdapat di daerah Gili Air, Gili Meno dan Gili Terawangan boleh dikatakan tidak ada sehingga apabila direncanakan dibangun suatu embung sangat kecil harus diambil dari daerah sekitarnya yang letaknya berdekatan dengan ketiga gili tersebut. Adapun bahan bangunan yang tersedia adalah ditujunkkan pada tabel 6. Sedangkan tanah di lokasi Desa Sokong, Kec. Tanjung, Lombok 
Barat, klasifikasi tanahnya berupa pasir pada kedalaman antara $1.00-2.00 \mathrm{~m}$ dengan sedikit bahan halus, dan data parameter tanah hasil pengujian didapatkan sebagai berikut (2):
Kadar air
$: 22,41 \%$
Berat isi
$: 1,29 \mathrm{~g} / \mathrm{cm}^{3}$
Berat isi kering $\quad: 1,05 \mathrm{~g} / \mathrm{cm}^{3}$
Berat jenis $\quad: 2,47$
Batas-batas Atterberg

Batas Cair
Batas Plastis
Indeks Plastisistas
$:-$
Analisa Butiran
Kerikil
Pasir
: $7,01 \%$
: $92,84 \%$
Lanau
: $0,144 \%$
Uji Kuat Geser
C
$: 0,06 \mathrm{~kg} / \mathrm{cm}^{2}$
Sudut geser
: $20,76^{\circ}$

Tabel 5. Satuan Geoteknik 1

\begin{tabular}{|c|c|c|c|}
\hline Jenis Tanah & Litologi & Sifat Fisik & $\begin{array}{lc}\text { Nilai Konus } & \text { N SPT/N } \\
\text { DPT }\end{array}$ \\
\hline $\begin{array}{l}\text { Satuan Geoteknik } 1 \\
\text { Pasir lempungan } \\
\text { hingga pasir } \\
\text { lanauan }\end{array}$ & $\begin{array}{l}\text { Warna abu-abu ke } \\
\text { hitaman, mengandung } \\
\text { banyak organik sisa } \\
\text { tumbuhan, sangat le- } \\
\text { pas, permeabilitas } \\
\text { sedang, ketebalan an } \\
\text { tara } 1.5 \mathrm{~m}-4.0 \mathrm{~m} \text {, se- } \\
\text { cara setempat, men- } \\
\text { capai } 28.0 \mathrm{~m}\end{array}$ & $\begin{array}{l}\mathrm{Wn}=23,43 \% \\
\gamma \mathrm{t}=1,57 \mathrm{~g} / \mathrm{cm}^{3} \\
\mathrm{G}=2,67 \mathrm{~g} / \mathrm{cm}^{3} \\
\mathrm{f}=15,52^{\circ} \\
\mathrm{c}=0,10 \mathrm{~kg} / \mathrm{cm}^{2}\end{array}$ & $2,7,7 \mathrm{~kg} / \mathrm{cm}^{2}$ \\
\hline $\begin{array}{l}\text { Satuan Geoteknik } 2 \\
\text { Lanau pasiran } \\
\text { hingga pasir } \\
\text { lempungan }\end{array}$ & $\begin{array}{l}\text { Pada kedalaman } \\
18 \mathrm{~m} \text { dijumpai } \\
\text { batugamping koral } \\
\text { setebal } 2 \mathrm{~m} \text {, dan diba- } \\
\text { wahnya terdapat la- } \\
\text { pisan lempung pasi- } \\
\text { ran, banyak mengan- } \\
\text { dung cangkang ke- } \\
\text { rang } \\
\text { Warna coklat muda, } \\
\text { agak lepas hingga } \\
\text { agak padat,permea- } \\
\text { bilitas sedang, } \\
\text { berbutir halus hingga } \\
\text { kasar, kompresibilitas } \\
\text { sedang, semakin ke } \\
\text { bawah lapisan pasir } \\
\text { ini bervariasi } \\
\text { berselang-seling } \\
\text { dengan lapisan pasir } \\
\text { kerikil permeabilitas } \\
\text { sedang }\end{array}$ & $\begin{array}{l}W n=46,10 \% \\
\gamma t=1,55 \mathrm{~g} / \mathrm{cm}^{3} \\
G=2,62 \mathrm{~g} / \mathrm{cm}^{3} \\
f=12,36^{\circ} \\
c=0,18 \mathrm{~kg} / \mathrm{cm}^{2}\end{array}$ & $\begin{array}{l}4-15 \mathrm{~kg} / \mathrm{cm}^{2} \\
(3-7) x /(2-6) x \\
\text { dan } \\
50->250 \mathrm{~kg} / \mathrm{cm}^{2} \\
16->30 x\end{array}$ \\
\hline $\begin{array}{l}\text { Satuan Geoteknik } 3 \\
\text { Lempung pasiran } \\
\text { hasil pelapukan } \\
\text { lanjut dari tufa } \\
\text { (endapan gunung api } \\
\text { Kuarter), tebal } \\
\text { antara } 1.5 \text { - } 8 \text { m. } \\
\text { Tebal aluvium antara2 - } \\
22 \mathrm{~m} \text {. }\end{array}$ & $\begin{array}{l}\text { Warna coklat keabu- } \\
\text { abuan, teguh hingga } \\
\text { kaku, plastisitas } \\
\text { tinggi, } \\
\text { permeabilitas rendah, } \\
\text { setempat-setempat } \\
\text { banyak mengandung } \\
\text { kerikil. Kedalaman } \\
\text { muka air tanah antara } \\
\text { 5-11 m. }\end{array}$ & $\begin{array}{l}W n=47,09 \% \\
\mathrm{gt}=1,36 \mathrm{~g} / \mathrm{cm}^{3} \\
\mathrm{G}=2,61 \mathrm{~g} / \mathrm{cm}^{3} \\
\mathrm{f}=12,44^{\circ} \\
\mathrm{c}=0,191 \\
\mathrm{~kg} / \mathrm{cm}^{2}\end{array}$ & $\begin{array}{l}6-10 \mathrm{~kg} / \mathrm{cm}^{2} \\
(5-14) \mathrm{x} / \\
\text { dan } \\
(4-11) \mathrm{x} \\
18-25 \mathrm{~kg} / \mathrm{cm}^{2}\end{array}$ \\
\hline
\end{tabular}


Tabel 6. Lokasi Bahan Bangunan

\begin{tabular}{|c|c|c|c|}
\hline No. & Lokasi & Jenis Batuan & Volume \\
\hline 1 & $\begin{array}{l}\text { Kp. Rea, Desa Gerung, } \\
\text { Kec. Gerung, +/- } 18 \mathrm{~km} \\
\text { arah selatan dr Mataram }\end{array}$ & $\begin{array}{l}\text { Andesit,warna abu-abu terang, } \\
\text { bersifat keras dan kompak, } \\
\text { sebagian terbreksikan }\end{array}$ & 37,50 juta meter kubik \\
\hline 2 & $\begin{array}{l}\text { Kp. Batusamban, Ds. } \\
\text { Jembatan, Kec. Gerung, } \\
\pm 19 \mathrm{~km} \text { arah selatan dari Mataram }\end{array}$ & $\begin{array}{l}\text { Andesit,warna abu-abu terang, } \\
\text { bersifat keras dan kompak. }\end{array}$ & $\begin{array}{l}\text { Diatas } 5,00 \text { juta meter } \\
\text { kubik }\end{array}$ \\
\hline 3 & $\begin{array}{l}\text { Kp. Batutumbuh, Ds. } \\
\text { Sekotong Barat, Kec. Sekotong }\end{array}$ & $\begin{array}{l}\text { Dasit, abu-abu terang, bersifat } \\
\text { keras dan kompak. }\end{array}$ & $\begin{array}{l}\text { Diatas } 100,00 \text { juta } \\
\text { meter kubik }\end{array}$ \\
\hline 4 & $\begin{array}{l}\text { Kp. Labuan Poh, Ds.La- } \\
\text { buan Poh, Kec. Sekotong }\end{array}$ & $\begin{array}{l}\text { Basalt, abu-abu kekuningan, } \\
\text { bersifat keras dan kompak. }\end{array}$ & $\begin{array}{l}\text { Diatas } 2,00 \text { juta meter } \\
\text { kubik }\end{array}$ \\
\hline 5 & $\begin{array}{l}\text { Kp. Sidemen, Ds. Ke } \\
\text { kait, Kec.Gunung sari }\end{array}$ & $\begin{array}{l}\text { Basalt, abu-abu kekuningan, } \\
\text { bersifat keras dan kompak. }\end{array}$ & $\begin{array}{l}\text { Diatas 2,00 juta meter } \\
\text { kubik }\end{array}$ \\
\hline 6 & $\begin{array}{l}\text { Kp. Kedondong, Ds. Ke- } \\
\text { kait, Kec.Gunung sari }\end{array}$ & $\begin{array}{l}\text { Andesit, abu-abu terang ber- } \\
\text { sifat keras dan kompak berke- } \\
\text { kar. }\end{array}$ & $\begin{array}{l}\text { Diatas } 8,00 \text { juta meter } \\
\text { kubik }\end{array}$ \\
\hline 7 & $\begin{array}{l}\text { Ds. Tanjung dekat Ds. } \\
\text { Gondang. } \pm 37 \mathrm{~km} \text { arah } \\
\text { utara dari Mataram }\end{array}$ & $\begin{array}{l}\text { Lempung merah bersifat plas- } \\
\text { tis dan kohesif. }\end{array}$ & $\begin{array}{l}\text { Diatas } 4,00 \text { juta meter } \\
\text { kubik }\end{array}$ \\
\hline 8 & $\begin{array}{l}\text { Kp. Rangau, Ds. Rangau, } \\
\text { Kec.Gangga, } \pm 56 \mathrm{~km} \\
\text { dari Mataram }\end{array}$ & $\begin{array}{l}\text { Endapan tufa batugunung, } \\
\text { bercampur scorial. }\end{array}$ & $\begin{array}{l}\text { Diatas } 2,00 \text { ratus ribu } \\
\text { meter kubik }\end{array}$ \\
\hline 9 & $\begin{array}{l}\text { Kp. Ruak Bangket, Ds. } \\
\text { Sukadana, Kec.Bayan }\end{array}$ & Endapan bom dan tufa lapili & $\begin{array}{l}\text { Diatas } 1,50 \text { juta meter } \\
\text { kubik }\end{array}$ \\
\hline 10 & $\begin{array}{l}\text { Kp. Amor-amor, Ds. } \\
\text { Amor-amor, Kec.Bayan, } \\
\pm 56 \text { km dari Mataram }\end{array}$ & $\begin{array}{l}\text { Endapan sungai dari sungai } \\
\text { Amor-amor }\end{array}$ & $\begin{array}{l}\text { Diatas } 150.000 \\
\text { meter kubik }\end{array}$ \\
\hline
\end{tabular}

Secara umum lempung hasil pengujian laboratorium dari Desa Tanjung dan Desa Sokong bersifat pasir halus lanauan, dengan berat jenis tanah berkisar antara 2,66 $\mathrm{t} / \mathrm{m}^{3}$. Berdasarkan hasil penyelidikan di lapangan didapatkan bahan urungan lempung di Desa Tanjung dekat Desa Gondang (arah utara dari Desa Gondang). Lempung tersebut mempunyai warna merah dengan plastisitas rendah, dengan volume sekitar 4 juta $\mathrm{m}^{3}$.

Lokasi kedua adalah di Desa Sokong, Kec.Tanjung didapatkan jenis tanah pasir dengan sedikit bahan halus. Berdasarkan hasil pengujian tentang batas-batas Atterberg, didapat cara untuk mengidentifikasi tanah ekspansif yaitu :

a. Seed et al, (1962) menunjukan bahwa tanah lempung di Desa Tanjung mempunyai Indeks Plastisitas < 18, dimana termasuk tanah lempung bersifat mengembang rendah.

b. Uji klasifikasi teknik menurut Skempton (1953) menunjukan tanah lempung yang diuji di Desa Tanjung tidak didapatkan nilai aktivitasnya $<0,75$ dimana tidak termasuk tanah ekspansif.

c. Uji klasifikasi tabel yang diperkenalkan oleh Chen (1988) dan Raman (1967), rentang Indeks Plastisitas tanah lempung di Desa
Tanjung menunjukan nilai < 12; hal ini menunjukan potensi pengembangan yang rendah.

d. Uji klasifikasi yang diperkenalkan Snethen et al (1977), tanah dengan batas cair 39,64\%, Indeks Plastisitas berkisar dengan batas $10,18-85 \%$ dari potensi pengembangan < $3 \%$ juga menunjukan tanah tersebut mempunyai kemampuan mengembang yang rendah.

Dari hasil pengujian pada contoh tanah diketahui bahwa pemadatan pada tanah ini mencapai berat kering maksimum sekitar 1,42 ton $/ \mathrm{m}^{3}$, dan kadar air maksimum sekitar $22,60 \%$. Berdasarkan kriteria yang disarankan menurut buku "Design of Small Dam", khususnya untuk jenis tanah lempung dengan batas cair yang tinggi disyaratkan bahwa kadar air yang harus dicapai sekitar $(25,5+1,2) \%$, sedangkan berat isi kering maksimum yang disyaratkan berkisar antara 1,504 ton $/ \mathrm{m}^{3}$. Berdasarkan hasil pengujian pemadatan yang telah dilaksanakan tersebut ternyata berat isi keringnya belum memenuhi syarat sedangkan untuk kadar airnya perlu adanya penambahan kandungan air.

Uji geser langsung yang telah dilaksanakan mendapatkan nilai parameter untuk 
hasil c berkisar $0,28 \mathrm{~kg} / \mathrm{cm}^{2}$, sedangkan nilai yang disyaratkan berkisar antara $\left(1,049 \mathrm{~kg} / \mathrm{cm}^{2}\right.$ $1.386 \mathrm{~kg} / \mathrm{cm}^{2}$ untuk $\mathrm{c}$ ), maka tanah yang diuji sebelum memenuhi kriteria tersebut. Sudut geser yang disyaratkan berkisar $19^{\circ}$ sedangkan hasil uji geser yang telah dilaksanakan $=28,26^{\circ}$, jadi parameter dari hasil uji geser langsung belum memenuhi katagori yang disyaratkan.

Uji konsolidasi yang dilaksanakan menghasilkan nilai parameter eo $=0,894$, sedangkan nilai eo yang disyaratkan antara 0,80 - 0,84. Berdasarkan hasil tersebut parameter hasil uji konsolidasi masih belum memenuhi syarat. Hasil uji permeabilitas pada tanah ini menunjukan angka koefisien permeabilitas = $1,455 \times 10^{-5} \mathrm{~cm} / \mathrm{det}$; hal ini menunjukan bahwa tanah tersebut tidak begitu kedap air.

Mengingat dan melihat daerah peninjauan di lapangan maupun parameter tanah yang telah dihasilkan dari pengujian di laboratorium, maka untuk daerah Gili Air, Gili Meno, maupun Gili Terawangan dapat diusulkan pembuatan embung sangat kecil. Dari parameter tanah yang didapatkan diketahui bahwa tanah bahan urugan yang didapat termasuk tanah dengan plastisitas rendah, dengan berat isi dibawah 1,2 t/m². Dari persyaratan yang ada dapat dinyatakan bahwa tanah hasil pengujian tidak cocok untuk bahan urugan. Berdasarkan hal-hal tersebut maka untuk ketiga Gili tersebut disarankan untuk dibuatkan embung sangat kecil dengan kapasitas dan dimensi yang disesuaikan dengan kebutuhan.

\subsection{Alternatif Jenis Bangunan Air}

Dimensi embung yang akan dibuat harus disesuaikan dan dapat mencukupi kebutuhan penduduk setempat. Sebagai bahan masukan dan perkiraan dari kebutuhan air di daerah kering yang pernah dilakukan oleh Pusat Litbang Pengairan pada tahun 1993/1994 pada 5 lokasi embung yang telah dibangun didapatkan data sebagai berikut :

a. Kebutuhan air untuk penduduk

$\mathrm{Qp}=150 \mathrm{lt} / \mathrm{hr} / \mathrm{kk}$

b. Kebutuhan air untuk ternak

$\mathrm{Qh}=200 \mathrm{lt} / \mathrm{hr} / \mathrm{kk}$

c. Kebutuhan air untuk kebun

$\mathrm{Qk}=450 \mathrm{lt} / \mathrm{hr} / \mathrm{kk}$

Jumlah penduduk yang ada di pulau Gili-Gili, Gili Air dengan asumsi kebutuhan minimum setiap 5 It/hr, sehingga diperlukan jumlah embung untuk setiap pulau Gili seperti terlihat pada Tabel 8.

Tanah yang ada adalah hasil pelapukan dari endapan vulkanik dengan ketebalan antara 1-2 m, berupa endapan aluvial yang umumnya adalah lanau sampai pasir. Nilai permeabilitasnya $(k)$ di lapangan dan di laboratorium antara $10^{-3} \mathrm{~cm} /$ det sampai ${ }^{-}$
${ }^{4} \mathrm{~cm} /$ det. Kondisi topografi di daerah Gili Air dan Gili Meno adalah dataran rendah, sedangkan di Gili Terawangan di bagian selatannya berupa perbukitan.

Tabel 7. Jumlah Kebutuhan Air Baku Untuk Gili-Gili, NTB

\begin{tabular}{|c|l|c|c|}
\hline No & \multicolumn{1}{|c|}{ Lokasi } & $\begin{array}{c}\text { Penduduk } \\
\text { (jiwa) }\end{array}$ & $\begin{array}{c}\text { Jumlah } \\
\text { (m2) }\end{array}$ \\
\hline \hline \multirow{2}{*}{1} & Gili Air Indah & 1.299 & 6.495 \\
2 & Gill Meno & 500 & 2.500 \\
3 & \multirow{2}{*}{ Gili Terowongan } & 1.106 & 5.530 \\
\cline { 3 - 4 } & & Total & 14.525 \\
\hline
\end{tabular}

Berdasarkan hasil analisis data lapangan dan laboratorium, jenis bangunan untuk penyediaan air baku yang sesuai di daerah penelitian antara lain embung sangat kecil. Embung sangat kecil adalah bentuk penampungan air dengan digali dan diurug yang ukurannya sangat kecil, yang besarnya disesuaikan dengan kebutuhan air baku yang akan digunakan. Bentuk yang paling kecil adalah kolam yang bisa digunakan sebagai penampungan air dan kolam ikan. Bila permeabilitas tanah cukup besar, maka tanah perlu diperkedap dengan semen, plastik, atau geotekstil, atau yang dicampur dengan bahan kedap air dari lokasi yang relatif dekat ${ }^{(4)}$.

Tabel 8. Jumlah dan Ukuran Embung Yang Diperlukan

\begin{tabular}{|c|c|c|c|}
\hline Lokasi & $\begin{array}{c}\text { Jumlah } \\
\text { Embung } \\
(\mathrm{bh})\end{array}$ & $\begin{array}{c}\text { Ukuran } \\
\text { Embung } \\
\left(\mathrm{m}^{2}\right)\end{array}$ & $\begin{array}{c}\text { Volume } \\
\text { Tampung } \\
\left(\mathbf{m}^{3}\right)\end{array}$ \\
\hline \hline $\begin{array}{c}\text { Gili } \\
\text { Terawangan }\end{array}$ & 10 & 300 & 1165 \\
Gili Air & 10 & 300 & 1165 \\
\hline
\end{tabular}

\subsection{Underground Dam}

Alternatif lain adalah menggunakan teknologi canggih, yang dari segi biaya cukup mahal yaitu bendungan bawah tanah. Kelebihannya antara lain, tidak mengganggu atau mengurangi lahan di permukaan tanah, kualitas air relatif lebih baik dibandingkan dengan penampungan air diatas permukaan tanah. Penempatan lokasi bendungan bawah tanah yang sesuai adalah pada lapisan tanah/batuan yang permeabel, seperti di daerah Gili Meno dengan dimensi lebar 0,5 m dan kedalaman $4 \mathrm{~m}$. 


\section{KESIMPULAN DAN SARAN}

\subsection{Kesimpulan}

1. Secara umum lempung hasil pengujian di Desa Tanjung dan Desa Sokong bersifat pasir halus lanauan, dengan berat jenis tanah berkisar antara $2,66 \mathrm{t} / \mathrm{m}^{3}$ dan $2,47 \mathrm{t} / \mathrm{m}^{3}$.

2. Berdasarkan hasil penyelidikan di lapangan didapatkan bahan urugan lempung di Desa Tanjung dekat Desa Gondang (arah utara dari Desa Gondang.) Lempung tersebut mempunyai warna merah dengan plastisitas rendah, dengan volume sekitar 4 juta $\mathrm{m}^{3}$.

3. Lokasi kedua adalah di Desa Sokong Kec.Tanjung didapat jenis tanah pasir dengan sedikit bahan halus. Berdasarkan hasil pengujian batas-batas Atterberg, didapatkan cara untuk mengidentifikasikan tanah ekspansif yaitu :

a. Tanah lempung di Desa Tanjung mempunyai Indeks Plastisitas < 18, yang termasuk tanah lempung bersifat pengembangan rendah.

b. Tanah lempung dari Desa Tanjung tidak didapatkan nilai aktivitasnya $<0,75$ dimana tidak termasuk tanah ekspansif.

c. Rentang Indeks Plastisitas tanah lempung di Desa Tanjung menunjukan nilai < 12; Hal ini menunjukan potensi pengembangan yang rendah.

d. Tanah dengan batas cair $39,64 \%$, Indeks Plastisitas berkisar antara 10,18-85\% dan potensial pengembangan $<3 \%$ juga menunjukan tanah-tanah tersebut mempunyai kemampuan mengembang yang rendah.

4. Hasil pengujian pada contoh memperlihatkan pemadatan pada tanah ini mencapai berat kering maksimum sekitar 1,42 ton $/ \mathrm{m}^{3}$, dan kadar air maksimum sekitar 22,60\%. Berdasarkan kriteria yang disarankan khususnya untuk jenis tanah lempung dengan batas cair yang tinggi disyaratkan bahwa kadar air yang harus dicapai sekitar $(25.5+$ $1.2) \%$, sedangkan berat isi kering maksimum yang disyaratkan berkisar antara 1.504 ton $/ \mathrm{m}^{3}$.

5. Berdasarkan hasil pengujian pemadatan yang telah dilaksanakan, berat isi kering belum memenuhi syarat, sedangkan untuk kadar air perlu adanya penambahan kandungan air.

\subsection{Saran}

1. Penampungan air berupa embung sangat kecil sebaiknya menggunakan bahan lempung yang sudah dicampur dengan semen atau menggunakan geoteksil sebagai bahan kedap air.
2. Dimensi embung yang akan dibuat harus disesuaikan agar bisa mencukupi kebutuhan penduduk setempat. Sebagai bahan masukan dan perkiraan dari kebutuhan air di daerah kering yang pernah dilakukan oleh Puslitbang Pengairan pada tahun 1993/1994 pada 5 lokasi embung yang telah dibangun didapatkan data sebagai berikut :

- Kebutuhan air untuk penduduk $Q p=150$ $\mathrm{lt} / \mathrm{hr} / \mathrm{kk}$

- Kebutuhan air untuk ternak $\mathrm{Qh}=200$ $\mathrm{lt} / \mathrm{hr} / \mathrm{kk}$

- Kebutuhan air untuk kebun $\mathrm{Qk}=450$ It/hr/kk

Total kebutuhan air $(\mathrm{Qu})=800 \mathrm{lt} / \mathrm{hr} / \mathrm{kk}$

3. Dengan memperhitungkan jumlah hari hujan sekitar 3 bulan untuk tiap tahun maka waktu kering diperhitungkan selama 9 bulan. Jadi kebutuhan air selama musim kemarau sebanyak $=9 \times 30 \times 800 \mathrm{lt} / \mathrm{hr} / \mathrm{kk}=216.000$ $\mathrm{lt} / \mathrm{hr} / \mathrm{kk}$

4. Berdasarkan luas Gili Terawangan = $2.480 .000 \mathrm{~m}^{2}$, Gili Air $=1.800 .000 \mathrm{~m}^{2}$, maka disarankan dibuatkan kondisi embung seperti dalam tabel di bawah ini.

Tabel 9. Lokasi dan Jumlah Embung

\begin{tabular}{|l|c|}
\hline \multicolumn{1}{|c|}{ Lokasi } & $\begin{array}{c}\text { Jumlah Embung } \\
\text { (bh) }\end{array}$ \\
\hline Gili Terawangan & 18 \\
\hline Gili Air & 10 \\
\hline
\end{tabular}

5. Karena jenis tanah di daerah penelitian relative mempunyai permeabilitas yang tinggi, maka untuk mengantisipasi besarnya bocoran / rembesan disarankan lapisan dasar maupun dinding dari embung diberi plesteran.

6. Untuk Gili Meno, berdasarkan kondisi geologi, maka underground dam cocok meskipun memerlukan biaya yang sangat mahal.

7. Penggunaan Geotekstil sebagai lapisan kedap air di daerah yang relative permeable diperlukan, khususnya di ketiga daerah Gili tersebut. 


\section{DAFTAR PUSTAKA}

1. S. Dun, Irving R Anderson, Loren, W.Kieler, Fred "Foundation of Geotechnical Analysis" John Willey \& Sons, 1980.

2. Djoko Sunarjanto, dkk, "Laporan Penyelidikan Pendahuluan Geologi teknik Jalan Antara Senggigi - Pemenang, Kabupaten Lombok, NTB", 1987.

3. Dept. Pertambangan dan Energi Kantor Wil.

Prop.NTB, "Peta Geoteknik Wil.Pengembangan Pariwisata Senggigi di Lingkungan Jalan Batulayar-Krandangan Kab. Lombok Barat, NTB.", Maret 1990.

4. Pusat Litbang Pengairan Badan Litbang Pekerjaan Umum, Dept. PU, "Kriteria Desain Embung Kecil Untuk Daerah Semi Kering Di Indonesia", Maret 1994 


\section{Abstrak}

Dalam rangka memenuhi kebutuhan air pada musim kemarau di daerah Nusa Tenggara Barat (NTB), khususnya di pulau pulau kecil di wilayah NTB diperlukan suatu sarana yang dapat menampung air hujan pada musim penghujan, sehingga persediaan air tersebut dapat dipergunakan saat musim kemarau. Karakteristik tanah di daerah pantai khususnya, selain datar juga tanahnya mengandung pasir, sehingga tanahnya cenderung mempunyai nilai permeabilitas yang cukup tinggi. Untuk membangun sarana bangunan air yang cocok dengan kondisi setempat maka, diperlukan suatu pengkajian terhadap alternative jenis bangunan air yang disesuaikan dengan kondisi geologi maupun ketersediaan bahan bangunan yang akan dipergunakan.

\section{Abstract}

In order to meet water needs during the dry season in West Nusa Tenggara (NTB), particularly on small islands in the NTB area needed a facility that can accommodate the rain water in the rainy season, so water supply can be used during the dry season. Characteristics of land in coastal areas in particular, other than flat land also contains sand, so the soil tends to have relatively high permeabilities. To build waterworks facilities suitable to local conditions then, required an assessment of alternative types of water structure adapted to the geological conditions and availability of building materials to be used. 